\title{
Education and Religion in Late Antiquity
}

\section{An Introduction}

\author{
Peter Gemeinhardt, Lieve Van Hoof \\ and Peter Van Nuffelen
}

\section{Jerome and Caesarius}

In a famous passage in his Letter 22 to the virgin Eustochium, written in 384, Jerome reports how he once dreamed that he was brought to trial, Christ himself being the judge. When he declared to be a Christian, Christ replied: 'You are lying! You are a Ciceronian, not a Christian, for wherever your treasure is, there will be your heart.' Utterly shocked, young Jerome swore that he would never again dare to possess or even read pagan writings - 'and if I ever do so, I have denied you'; ${ }^{1}$ that is, he would have acted like Peter disowning Jesus during the trial at Pilate's court. Addressing Eustochium, Jerome pointed out that a Christian virgin should avoid any contact with and contamination by the texts commonly used at the grammar and rhetorical schools, and instead acquire a genuinely Christian education, for 'what has Horace to do with the Psalter? what Virgil with the Gospels? what Cicero with the Apostle?'2 To put it simply: away with all the pagan stuff?

As is well known, this was by no means Jerome's last word concerning the rejection, reception or appropriation of pagan education by pious Christians. It is less well known that this story is re-enacted in the mid-sixth century in the Life of Caesarius of Arles, one of the most influential bishops in early Merovingian Gaul. In his youth, Caesarius went to the Isle of Lérins in order to live an ascetic life. Neglecting the admonitions of his fellow monks to moderate his ascetic efforts, he fell ill due to overexertion and was rescued by his family to the city of Arles. Here, Caesarius was supposed to acquire a solid education by studying with the famous teacher of rhetoric, Julianus Pomerius. Like Jerome, however, Caesarius soon experienced a terrifying dream: Tired by the endless study of classical school-texts, Caesarius fell asleep, using the book as a pillow for his shoulder. Suddenly he became aware that a dragon had appeared and was about to devour his shoulder and arm. Deeply threatened by this dream, Caesarius like Jerome - immediately chose to despise any secular skills, knowledge and glory. Or, more precisely, he despised acquiring such competences at school, while he did not deny their usefulness for a Christian preacher: 'He knew well that the jewellery of perfect oratory will not be wanting in those who have gained their insights in a spiritual manner. ${ }^{3}$ 


\section{Peter Gemeinhardt et al.}

Both texts aim at digging a gap between secular education and Christian teaching, that is, between the wisdom of the world and the wisdom of God, tacitly referring to the First Letter to the Corinthians 1, 2 and representing a longstanding inner-Christian discourse concerning values and threats of secular education to religious conduct. And yet, there are significant differences with respect to genre, context and audience: Jerome, in the last quarter of the fourth century, uses the classical epistolographical style with its rhetorical features in order to persuade Eustochium (or in fact her mother, Paula) to acquire a Christian education. He thus employs the literary code of written communication. Therefore, as was already registered by Rufinus, the form of his letter consciously contradicts the content of the narration. And of course Jerome did not at all cease to make use of his ample knowledge of classical literature! When Rufinus accused him of still quoting Horace, Cicero and Virgil, Jerome indignantly replied that already the Old Testament prophets had warned against taking dreams too serious. ${ }^{4}$ What is more important, Jerome claims that if he still remembered and quoted the classics, this would not testify to his continuous reading but to the deep and indelible impregnation by such knowledge acquired at school: 'Shall I drink from the river Lethe - according to the fables of the poets - in order to avoid the accusation of knowing what I have learnt?'5

The addressees of Jerome's letters were noble men and women in Rome and other cities of the empire, longing for ascetical instruction while being eager to maintain their education as part of their Christian life. The Life of Caesarius, in contrast, was written for an audience that was still capable of written communication but confronted with the disintegration of Roman administration and educational institutions under 'barbarian' rule. The Life of their venerated bishop aimed at advocating a Christian way of life within a radically changed world, without any hope to restore ancient ideals of Romanitas in Gaul, including a thorough instruction in the artes liberales. Thus, it is no longer an epistolographical but instead a hagiographical discourse within which the anonymous authors situate their writing. Caesarius, however, was placed on the threshold of the Roman and the barbarian epoch: himself a man of letters, he embodied the uselessness of such educational values in post-Roman society and thus represented change, while Jerome argued for the coexistence of classical and Christian education, the former functioning as propaedeutic for the latter (a model already crucial to the philosophical and theological instruction by Origen in Alexandria and Caesarea). ${ }^{6}$

Jerome's Letter 22 and the Life of Caesarius of Arles thus witness to continuities and changes in the perception of education and religion during the fourth to sixth centuries. This period to which we refer as Late Antiquity has famously been declared a period of 'decline and fall' in general by Edward Gibbon and in particular, concerning education, by Henri-Irénée Marrou (although Marrou later came to view this epoch in a more nuanced perspective). ${ }^{7}$ It has been denounced as a time of 'décadence', the contemporaries not being able to live up to the values of their forefathers, at best only incompetently reproducing them. ${ }^{8}$ In recent times, however, the focus has shifted to Late Antiquity as an epoch sui 
generis, that is, a period in which classical Hellenistic and Roman educational values were merged with a new approach to education from a religious perspective. Peter Brown has highlighted how classical rhetoric was fundamental to the imperial discourse even under the auspices of the Christianisation of empire; ${ }^{9}$ Averil Cameron has pointed to the fact that Christian discourse depended on the learning acquired at school even when such learning was rejected outright, terming this phenomenon 'the rhetoric of paradox'. ${ }^{10}$ All in all, with 'Late Antiquity' we face a time of intensified debate about classical texts and skills, and of astonishing innovations in combining such learning with the demands of the day. And to this debate, the relationship of education and religion was fundamental.

\section{Scope of the Present Volume}

As the texts quoted above indicate, the attitude of late ancient Christians towards classical education was complex - and becomes even more complex when looking beyond the Latin part of the empire to Greek Patristic and Christian Oriental literature and, moreover, to non-Christian texts and traditions. In recent years this field has been extensively studied, with particular attention on the different theoretical positions that can be found among the Church Fathers, a development to be observed not only in Christianity but also in Neo-Platonic philosophy and paralleled in Jewish religion and early Islam. ${ }^{11}$ The respective attitudes ranged, generally speaking, from enthusiastic assimilation to outright rejection, which sometimes covered up implicit adoption. The present volume seeks to shift attention away from such explicit statements that have been used to construct 'the' Christian attitude towards education. It argues that there is no simple way to define this attitude, for at least three reasons.

First, the Christian position towards teaching and classical learning was, as said, complex at any given time, due to the fact that the Christian practice is always accompanied by a reflection on that very practice. In other words, teaching could never be an unreflected practice for Christians in Late Antiquity, as they were acutely aware of its non-Christian origins. This did not necessarily imply immediate rejection, but the reflection on the practice could raise doubts about one's own training (as it did with Jerome) or be exploited in protreptic and polemic. ${ }^{12}$ This necessitated, in turn, Christian adaptations that by and large kept the classical form but substituted Christian content. ${ }^{13}$ Instead of identifying any of these as 'the' Christian attitude, they should be understood as cas de figure generated by the Christian second-order reflection on education.

Second, social contexts produce particular forms of learning, obviously relying on existing models. Late Antiquity was a time of tremendous social change, and we can thus expect substantial differences across time and the Mediterranean. In this volume, this change is present in many ways:

- the rise to prominence of languages such as Coptic and Syriac; ${ }^{14}$

- the decline of traditional social classes in North Africa, defusing the traditional identification of secular learning with paganism; ${ }^{15}$ 
- the continued presence of a civic elite in the Syriac realm, expressing demand for education; ${ }^{16}$

- as a mirror image of the decline of traditional schools, the rise of learning in specific social contexts, such as the church and liturgy, monasteries and episcopal legal and rhetorical practice. ${ }^{17}$

This last development, in turn, may have allowed to reach out to lower social classes that traditionally received little education. ${ }^{18}$ This, however, takes place against the background in which the ideal of classical education as exemplified in the traditional teacher of rhetoric remains strong. ${ }^{19}$

Third, the form in which education is practised or opinions about it are expressed shapes the argument itself. Genre (however defined) is thus an important factor in shaping positions on education. As we have seen, there is a difference between a letter to noble Roman ascetics and the life of a saintly bishop written for other Gaulish bishops, and there is an analogous difference between hidden combination and overt rejection of classical education by Christians. In both cases, the subtext may lead to the conclusion drawn by Augustine in On Christian Doctrine that grammatical and rhetorical skills are simply necessary for interpreting the Bible and Christian preaching. The precious little treatise of Basil of Caesarea - Address to Young People on the Right Use of Greek Literature - witnesses to another approach to classical learning informed by critical reflection from a Christian point of view. ${ }^{20}$ Many texts may seem to draw strict lines of separation between secular and Christian learning. Yet, if we look more closely at specific texts, we shall see more nuanced perspectives crop up which are as much part of the Christian discourse on education as the more strident rejections. Conversely, pedagogical concepts could strongly impact on the production of religious literature and determine the choice of genre: processes of selection, condensation, rhetorical elaboration and forgery turn out to be driven by specific protreptic aims. ${ }^{21}$ This process may become most tangible in translations: the translator had to make a series of conscious choices ranging from which text to translate, over what parts of it to omit or change, to how to translate specific words. ${ }^{22}$

By highlighting these three factors, this volume wishes to shift attention from statements to strategies, so as to enrich our understanding of the creative Christian engagement with classical ideals of education. In order to provide a more diversified sample than often is brought together, the chapters study texts in Latin, Greek, Coptic and Syriac, and usually focus on little-studied texts and examples (letters, historiography, sayings, orations and sermons, acts of councils, philosophical texts, hagiography, translated works from classical antiquity, papyri). The volume thus illuminates the close connection between specific educational purposes on the one hand, and the possibilities and limitations offered by specific genres and contexts on the other: instead of seeing attitudes towards education in late antique texts as applications of theoretical positions, it reads them as complex negotiations between authorial intent, the limitations of genre and the context of performance. The volume covers three centuries, from 
the fourth to the seventh, a period of momentous change in the Mediterranean. Change is indeed prominently present in all chapters, for it is a consciousness of change and difference that shapes many of the debates this volume chronicles. Yet we do not wish to offer a history of attitudes towards education from the fourth to the seventh century. Rather, the thematic organisation of the four parts invites the reader to notice how similar queries and responses would emerge in very different circumstances. In thus shifting attention to specific texts and themes, we hope to heighten our awareness of the richness and complexity of the way late ancient Christianity grappled with education.

\section{Summary of the Chapters}

So far we have focused on the overarching questions and arguments of the present volume. Its 12 chapters have been divided into four parts, according to their thematic coherence. The first part contains three chapters on monastic education, and hence focuses on Egypt. The second part highlights one particular and widespread form assumed by education: gnomic sayings. The third collects three chapters on three very different constructions of Christian protreptic, whereas the last focuses on the relationship between secular and religious learning and the perception of that distinction.

Part I, entitled Monastic Education, addresses the locus classicus supposed to demonstrate how Christians turned away from classical education: the uncouth Egyptian monks. It contributes to a re-evaluation of monastic education, in terms of both its fundamental continuity with classical education and its distinct features due to the peculiar type of community monasteries constituted. In the first chapter, 'Early Monasticism and the Rhetorical Tradition: Sayings and Stories as School Texts', Lillian Larsen adduces descriptive and documentary evidence to show that classical rhetoric continued to frame monastic education. Given the integral role accorded to gnomic sentences and maxims in ancient education, it argues for the particular merits of reading collections of monastic apophthegmata in light of ancient pedagogical models. They incorporate traditional rhetorical prescriptions, and as such may have served the same purposes as ancient maxims, that is, to progress in virtue and in literacy. The next chapter, by Janet Timbie, tackles a similar problem, but with an even greater acuity: the training of Coptic-speaking monastic leaders. The monastic leaders of late ancient Egypt are mainly known to us through their writings in Coptic. This raises the question as to the kind of education they received (Coptic or Greek) and where they were instructed (inside or outside of the monastery). She argues that monasteries were literate communities and that monks were expected to acquire a modicum of reading and writing skills. This could be acquired in the monastery itself, but higher education was probably not institutionalised in monasteries, even if many would learn in practice from listening to educated brothers and reading their works. Most monastic leaders, however, had acquired some training in Greek before embarking on an ascetic life, and when writing in Coptic they applied the rules taught then, in particular the following 


\section{Peter Gemeinhardt et al.}

of established models (increasingly, but not exclusively, the Bible). We witness thus a transfer of rules developed in Greek education to Coptic writing, without proper higher education in Coptic being developed. In the third and last chapter of this section, Edward Watts looks more closely at the social structures underpinning monastic education. Individual monks were put under the guidance of a mentor, who in turn obeyed superiors. Teaching and the affirmation of authority therefore went hand in hand. Personal authority was crucial, as the pupil-mentor relationship was individual and direct. At the same time, this authority was affirmed in the nature of the Pachomian community as a hierarchical community that expressed the continuity between Apostolic preaching and Pachomian communities. This self-understanding was instilled through oral exegesis of biblical passages as well as through the circulation of anecdotes about past leaders. This happened both in formal settings such as house meetings and in individual encounters. The structure of the community thus favoured teaching, and such teaching reinforced the identity and cohesion of the community.

The second part, Gnomic Knowledge, concentrates on a certain kind of didactic tool employed in philosophical and religious literature. It already surfaced in the chapter by Larsen, and is now explored through evidence from outside Egypt. Yannis Papadogiannakis ('An Education through Gnomic Wisdom: The Pandect of Antiochus as Bibliotheksersatz') reassesses the nature of the Pandect of Antiochus, the seventh-century author of a set of moralising homilies. Approaching them with a modern spirit searching for systematic exposition, scholarship has tended to dismiss them as derivative and superficial. By situating them in the rhetorical and philosophical tradition of the ancient world, Papadogiannakis shows that they offer condensed instruction which served the needs of meditation and memorisation of a monastic community. Interiorised, the gnomic morality became a guidance for action in real life. In his chapter, Alberto Rigolio asks whether Syriac translations of Greek secular literature might represent 'a gnomic format for an instructional purpose'. A series of Syriac translations of Greek moral treatises - in particular works by Plutarch, Lucian and Themistius were made in the fifth and sixth centuries. The close analysis of the modifications the texts underwent in the process of translating shows a clear influence from wisdom literature: through the use of aphorisms, moral expansions and other literary tools, the knowledge transmitted acquires a gnomic nature. Rigolio draws attention to parallels with the Dialogues of John of Apamea and the didactic situation they presuppose: in order to convey his message to an audience that had received little instruction, the interlocutors use tools such as stories and moral sentences. The translations, so Rigolio suggests, may have functioned in a similar educational context. In the final contribution to this part, Jan Stenger tackles the question of 'Athens and/or Jerusalem' - prominent already in Tertullian - with respect to Basil's and Chrysostom's views on the didactic use of literature and stories. His chapter provides some background to the approaches to education witnessed in Antiochus and the Syriac translations. John Chrysostom and Basil of Caesarea set out very different conceptions of Christian education. John expects the complete Christianisation of the household and the 
abandonment of classical learning: he identifies the elite habitus of paideia as one of the causes of their lack of moral virtue, and hopes that the Christian household can become the place of a Christian education. Basil, by contrast, accepts the value of traditional education, even towards virtue, but sees Christianity as capping the achievement. Both, thus, insist on the moral value of education but judge the role of traditional education differently. Both, however, insist on the use of stories and quotations to make the education they have to offer accessible to their audiences.

The third part, Protreptic, shifts attention away from precise educational context towards broader didactic uses of texts. It focuses on how texts function as protreptic and how they therefore reflect and presuppose social conditions and a certain valuation of education. The chapter by Peter Gemeinhardt - 'Christian Hagiography and the Rhetorical Tradition: Victricius of Rouen, In Praise of the Saints' - analyses the use of rhetoric for establishing a 'community of saints' formed by relics of deceased martyrs, on the one hand, and by the Christian people of Rouen, on the other hand. Victricius employs the rhetorical devices of an imperial 'adventus' in order to welcome the saints in his town. Moreover, he develops a perception of holiness as preserved even in the tiniest parts of bodily remains of the martyrs, so that their holiness may be materially present all over the world; but, finally, Victricius goes on to argue that saints are not only to be venerated but also imitated. Thus, teaching the imitation of Christ is fundamental to the veneration of relics, and by preaching as well as by performing the present panegyric, the bishop functions as spiritual teacher of his flock. The next chapter, by Lieve Van Hoof, shifts attention to the genre of letters. Twentysix letters document an exchange of views between Libanius, the famous pagan teacher of rhetoric from Antioch, and Basil of Caesarea, the equally famous Father of the Church. Besides providing additional proof that this is a forged collection, a close reading of the letters shows how the forger subtly shapes the collection as a protreptic for aspiring members of the elite. They are invited to reconsider the role played in their life by rhetoric - identified as a pagan practice and associated with pride - and to assimilate themselves with Basil, who not only surpasses Libanius in rhetoric and virtue, but also decided to embrace an ascetic life. A subtle hierarchy is thus evoked, whereby Christian rhetoric surpasses its pagan counterpart, but is itself overcome by a higher way of life. The third part concludes with a chapter by Derek Krueger, on the use of biblical references in the seventh-century Life of Mary of Egypt. The text presupposes that Mary learns in church about Scripture. This reveals, in turn, that many biblical echoes in contemporary texts reflect attendance at the liturgy, which functions as the main conduit for the transmission of knowledge. An allusion to a hymn by Romanus the Melodist confirms this. The Life itself, finally, also partakes in that process: it was itself read in a liturgical context and thus provided instruction in a liturgical setting.

The contributions by Gemeinhardt and Van Hoof already touch on the religious valuation of education as pagan or Christian. The third part tackles this theme explicitly. Peter Van Nuffelen takes the Conference of Carthage (411), 
convoked by the Emperor Honorius to allow Catholics and Donatists to settle their differences through debate, as a springboard to highlight how Christian use of education was usually accompanied by a second-order reflection on that use. Indeed, one of the issues debated at Carthage was what the issue at stake was: if it was a legal issue, the bishops would plead according to the rules of forensic (that is, secular) rhetoric; if the argument was theological, they would revert to an ecclesiastical mode of arguing, which relied on the Bible. Such an opposition was not neutral: the former was negatively characterised, allowing the second to emerge as the proper way to settle the issue. If shown with particular clarity at the conference, such distinctions can be found elsewhere.

Besides demonstrating the well-known preference for ecclesiastical learning, they also demonstrate an awareness that different types of argument and learning were appropriate in different social contexts and for different subjects; and they should, at any rate, not be misconstrued as wholesale rejections of secular learning or of debate. Rather, the normative views attached to certain practices and types of learning were used as part of the argument itself; and the sometimes heated debates about education in Christian circles can be understood, so Van Nuffelen argues, as reflecting on the Christian integration of a first-order use and a second-order reflection on this use.

In the history of the Vandal persecution, written by Victor of Vita towards the end of the fifth century, Konrad Vössing notes less of a need to distinguish secular from ecclesiastical learning. Victor, a clearly ecclesiastical author, praises classical authors without feeling the need to introduce the qualifications or caution that was standard in the age of Augustine. Rather than seeing this as a feature typical for Victor, Vössing argues that this attitude reflects a general shift in attitudes due to the social changes brought by the Vandal conquest: whereas before the conquest power was held by the provincial elite for which classical learning was second nature, the Vandal kings established their power on faithfulness to Arianism and to a Vandal, non-Roman, identity. Traditional elite and Catholic Church now faced the same enemy. This led to an integration of both groups, but also removed much of the social tension that underpinned earlier debates about education. Thus, learning in fifth-century Africa is not only marked by a gradual erosion but also by a wider social acceptance.

Finally, Daniel King shows how the Syriac world engaged with the same issues surrounding the heritage of classical education as the Greek- and Latin-speaking regions. One reason for this is that the Syriac world remained for a long time bilingual Greek-Syriac, and thus had direct access to Greek texts and the debates surrounding them. At the same time, Syriac texts and education rapidly gained prestige. Emphasising how Syriac authors adopted the standards and contents of Greek education, for example in grammar and rhetoric, and how the same aspiration of a rise in social status was attached to it, he demonstrates that this content and assessment survived the decline of urban structures and the transferral of education towards monasteries, which became from the sixth century onwards centres of intellectual activities. Yet learning also survived outside formal institutions: philosophy, for example, never seems to have been taught at 
schools, but was rather associated with the practice and teaching of medicine (as it was in the Greek-speaking world too).

\section{Notes}

1 Jerome, Letter 22.30.4-5: Interrogatus condicionem Christianum me esse respondi. Et ille, qui residebat: 'mentiris, ait, Ciceronianus es, non Christianus; ubi thesaurus tuus, ibi et cor tuum' ... . Domine, si umquam habuero codices saeculares, si legero, te negaui.

2 Jerome, Letter 22.29.7: quid facit cum psalterio Horatius? cum enangeliis Maro? cum apostolo Cicero? nonne scandalizatur frater, si te uiderit in idolio recumbentem?

3 Life of Caesarius of Arles 1.9 (SChr 536, 160.18-20 Delage): Igitur contempsit haec protinus, sciens quia non deesset illis perfectae loquutionis ornatus, quibus spiritalis eminet intellectus.

4 Jerome, Apology against Rufinus 1.31 (CCL 79, 31.5-8 Lardet).

5 Jerome, Apology against Rufinus 1.31 (CCL 79, 30.52-3 Lardet): Bibendum igitur mihi erit de lethaeo gurgite, iuxta fabulas poetarum, ne arguar scire quod didici?

6 See Origen's Letter to Gregory Thaumaturgus.

7 Cf. Marrou 1938 and 1978.

8 For a new approach to the 'décadence' paradigm see now Formisano/Fuhrer 2014.

9 Brown 1992.

10 Cameron 1991.

11 Gemeinhardt/Günther 2013.

12 This is discussed in the contributions by Gemeinhardt, Van Hoof, Van Nuffelen and Vössing.

13 See, in particular, Larsen and Rigolio.

14 See Timbie, Rigolio and King.

15 See Vössing.

16 See King.

17 Respectively Krueger, Timbie and Watts, Van Nuffelen.

18 See Timbie and Rigolio.

19 See Van Hoof.

20 See Stenger.

21 See Larsen, Papadogiannakis, Rigolio, Van Hoof.

22 See Rigolio, King. 